\title{
Climate change and young people in Uganda: a literature review
}

\section{Introduction}

"No continent will be struck as severely by the impacts of climate change as Africa."

(United Nations Environment Programme, undated).

Climate change disproportionately affects young people. The impact of climate change upon the livelihoods of young people in Uganda--now and in the future-presents two contradictions. Firstly, the poorest and most vulnerable young people are the most exposed to climate shocks - despite their negligible role in driving climate change. Secondly, these same young people offer insights which could be instrumental in addressing climate change, yet such insights are rarely sought. This scenario is not unique to Uganda; rapid population growth in the rest of the countries in the East and Central African countries, has led to large youth populations whose circumstances and geographical location combine to make them particularly vulnerable to the impacts of climate change (Barford et al., 2021). In part, this vulnerability stems from livelihood opportunities becoming increasingly constrained in the face of growing competition for jobs driven in part by population pressure, in a context of insufficient labour market demand. This has been exacerbated by recent economic shocks and increased worklessness associated with the COVID-19 pandemic (ILO, 2020; Fox et al., 2020, Barford et al., 2020). Insufficient work and working poverty equate to fewer resources with which an individual or household can build resilience to both rapid and slow onset environmental change (Adger et al., 2014). Thus poverty and climate change can aggravate one another (Mfitumukiza, 2021).

Uganda, positioned within its wider East African regional context, is expected to be on track for shorter wet spells and a slight increase in heavy rainfall (Shepard, 2019). Yet these projected environmental changes have strong geographical and temporal variability, which are smoothed when focusing on annual averages and regional trends. Other predictions emphasise the increases in high intensity and sporadic rainfall events (Christensen et al., 2017). With an estimated population growth of $2.8 \%$ per year, in an environment of shrinking natural resources, including land availability and water resources, the Intergovernmental Panel on Climate Change (IPCC) describes climate change as a threat multiplier, exacerbating existing problems including conflicts and economic insecurity.

Home to the Congo Basin forests and the second largest tropical forest area in the world, many Central African countries to the north and south of the Congo Basin 
forest are projected to be severely affected by climate change. Impacts such as increased variability in agricultural production could exacerbate the refugee situation in the region arising from the migration of the diverse populations from these countries (including young people) highlighting the need for climate change adaptation options (Davis \& Gephart, 2018). Many Central African countries have sought mitigation and adaptation funding to protect their forestry heritage (Clionadh et al., 2015). With many countries in the Central and Eastern Africa region currently categorized in the 'least developed country' group (table 1), it is a difficult combination of social and environmental factors that prompt this literature review, in which we seek to understand the challenges to climate change mitigation and adaptation by the youth.

The shocks and underlying stressors associated with climate change - drought, floods, heat stress, fires, sea level rise, storm drainage, pests and other impacts are expected to become more frequent and intense (Karen, 2019). The alternative scenario is that adaptation and mitigation be incorporated meaningfully and quickly into development policies and investments (ibid.). In Uganda, young people are recognised as being particularly vulnerable to climate change shocks, including the landslides in Bududa, locust infestation in Karamoja and neighbouring regions, floods in Bundibugyo and Kasese districts, and the rising levels of water in Lake Victoria (Mugyenyi et al., 2020). Throughout Uganda, young people are reeling from prolonged droughts, internal displacement, destruction of properties and infrastructure and reduced erratic and unpredictable rainfall which is affecting agriculture production and food security. The situation has been compounded by the COVID-19 pandemic which is not only claiming lives but has also led to the loss of jobs and livelihoods, especially in the informal sector (Mugyenyi et. al., 2020). Large numbers of young people are involved in agricultural work and this sector is especially exposed to climate change (Karen, 2019). Studying the impacts of climate change on young people in Uganda offers in depth insight into some of the challenges faced more widely in the region.

Besides, the impacts of climate change are gendered. A recent UNICEF study demonstrates that climate change disproportionately impacts women and young people (Godfrey \& Tunhuma, 2020), and leaving young women who embody both these demographic profiles particularly exposed. Many of the health risks due to climate change show gender differentials, including the risk to life. In Burundi, Rwanda and the Democratic Republic of Congo for instance, natural disasters such as droughts, floods and storms kill more young women than young men. Additionally, young women disproportionately suffer the health consequences of nutritional deficiencies and the burdens associated with travelling further to collect water when this resource is harder to access (Godfrey \& Tunhuma, 2020). The impacts of climate change are unevenly felt; those with the least power and resources are the worst impacted, further exacerbating the existing inequalities. 
This paper assesses the peer-reviewed and grey literature on young people and climate change in Uganda and other Central and Eastern African countries (table 1; FAO, 2021). In undertaking this review, we address three key questions (box 1): (i) What are the diverse livelihood strategies of young people in rural and urban settings in Uganda, and in the wider Central and Eastern Africa regions?; (ii) How does climate change impact upon young people's lives and livelihoods?; and (iii) What are the solutions to the challenges faced by young people in coping with climate change?

The next sections of this paper present the methodology used for this literature review followed by the findings of the observed and expected regional environmental changes associated with anthropogenic climate change, the youth demographics of the regions and how young people are getting by. They also present the impacts of climate change on young people and how they are responding to the phenomenon and a commentary on the policy responses. The paper ends with a discussion and conclusions.

\begin{tabular}{|l|l|l|}
\hline \multirow{4}{*}{ Central Africa } & Countries & Least developed country \\
\cline { 2 - 3 } & Central African Republic & No \\
\cline { 2 - 3 } & Chad & Yes \\
\cline { 2 - 4 } & Congo & Yes \\
\cline { 2 - 4 } & Democratic Republic of Congo & No \\
\cline { 2 - 3 } & Equatorial Guinea & No \\
\cline { 2 - 3 } & Ees & \\
\hline
\end{tabular}




\begin{tabular}{|l|l|l|}
\hline \multirow{4}{*}{} & Gabon & No \\
\cline { 2 - 3 } & São Tomé and Príncipe. & Yes \\
\hline \multirow{5}{*}{ Eastern Africa } & Burundi & Yes \\
\cline { 2 - 3 } & Djibouti & Yes \\
\cline { 2 - 3 } & Eritrea & Yes \\
\cline { 2 - 3 } & Ethiopia & Yes \\
\cline { 2 - 3 } & Kenya & No \\
\cline { 2 - 3 } & Rwanda & Yes \\
\cline { 2 - 3 } & Somalia & Yes \\
\cline { 2 - 3 } & South Sudan & Yes \\
\hline
\end{tabular}

Table 1. Country overview. Least developed countries in Central and Eastern Africa, sourced from: UN Committee for Development Policy. 2020. Regional definitions for Central and Eastern Africa, sourced from FAO, 2021.

\section{Methodology}

The methodology for this literature review is designed to not only rigorously review but also summarise understandings of this area (Gough et al., 2017, Sambunjak et al, 2017). The approach is to review documents using clearly formulated questions (see box 1), with systematic and explicit criteria to select relevant research (Ford \& Pearce, 2010). Thus, the search terms are fully reported, alongside stating the criteria for inclusion and exclusion of articles, documenting publications excluded in the analysis along with those included (table 2). This more systematic approach to literature reviews is widely used in the health sciences, yet remains rare in the social sciences and humanities. 


\section{Box 1: Research questions}

(i) What are the diverse lives and livelihood strategies of young people in rural and urban settings in Uganda, and in the wider Central and Eastern Africa regions?

(ii) How does climate change impact upon young people's lives and livelihoods?

(iii) What solutions are there to the challenges faced by young people?

The literature review process focused primarily on peer reviewed journal articles, and official policy documents. In addition, the review process drew upon the grey literature of NGO, government, and international organizations' reports. The following databases were searched between May and October 2020: Ebscohost, JSTOR, Wiley Online Library, Springer eBooks, Project MUSE, University of Chicago journals, Palgrave Macmillan Journals, ACLS Humanities E-Book (HEB), and Google Scholar. Table 2 reports the key Boolean search terms used. Overall, these searches yielded 117 articles which were reviewed to confirm relevance to the study based upon the abstracts and subsequently full text. In the end, 62 articles met the inclusion criteria (table 2).

\begin{tabular}{|c|c|c|}
\hline Boolean search terms & Inclusion criteria & Exclusion criteria \\
\hline $\begin{array}{l}\text { "youth*" } \\
\text { "climate change*" } \\
\text { "livelihoods" } \\
\text { "Uganda } \\
\text { "youth policy" } \\
\text { "Karamoja" } \\
\text { "Jinja" } \\
\text { "East Africa" }\end{array}$ & 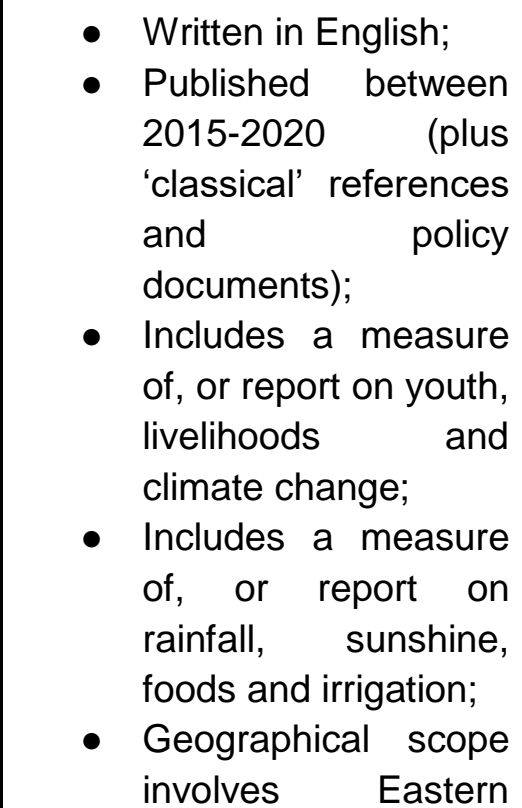 & $\begin{array}{l}\text { - Theoretical studies } \\
\text { with no empirical } \\
\text { findings; } \\
\text { - Intervention studies } \\
\text { that did not provide } \\
\text { pre-intervention or } \\
\text { control data. }\end{array}$ \\
\hline
\end{tabular}




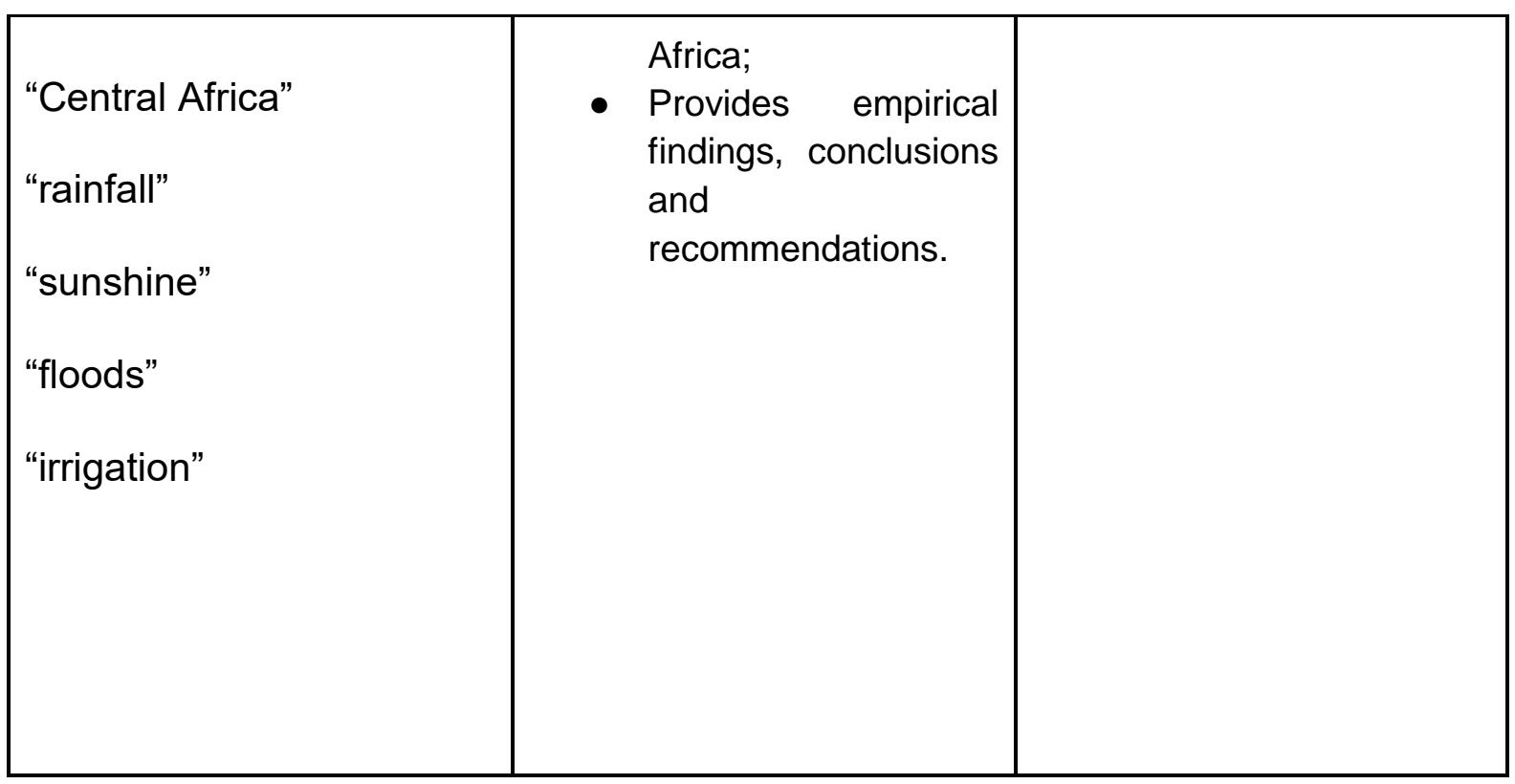

Table 2. Search terms and criteria for systematic literature search

A template was developed to systematically summarize the articles in a fine grained manner, under the broad headings of: 1) Study details; 2) Evidence on the nature and pace of climate change in Eastern Africa; 3) Youth livelihoods and 4) Recommendations on youth responses to climate change (table 3). The template was used to delineate the themes of interest and communicate these clearly amongst the research team. The template was developed based upon the team's existing expertise on youth livelihoods and climate change in Uganda, and unexpected findings were incorporated through the category 'other'. Tabulating findings allowed for quick comparisons and overview of the emerging themes, and also sought to identify gaps in the literature. Analysis was conducted using the Framework Analysis Approach (Ritchie \& Spencer, 1994) which compares the content of the articles across the four themes identified to answer the research questions (box 1), namely: youth livelihood strategies in rural and urban settings, youth policy and climate change, the impact of climate change on young lives, and solutions to the challenges faced by the youth in dealing with anthropogenic climate change. Looking for patterns within data, and allowing emerging themes to then become analytical categories facilitated analysis (after Fereday et. al., 2006). It is these themes that structure the findings sections.

\begin{tabular}{|l|l|}
\hline Parent category & Specific questions \\
\hline Paper details & Full reference of publication \\
\hline Climate change & Evidence on the nature and pace of climate change \\
\hline
\end{tabular}




\begin{tabular}{|c|c|}
\hline in Uganda, and & Information on quick or slow onset events \\
\hline $\begin{array}{lr}\text { Central } & \text { and } \\
\text { Eastern } & \text { African }\end{array}$ & Locations which worst are affected, and why \\
\hline & Locations which are less affected, and why \\
\hline & Comment on data quality \\
\hline & Identification of gaps in the literature \\
\hline & Other \\
\hline Youth livelihoods & What work young people do (inc. unpaid and domestic work) \\
\hline Eastern Africa & Young people's aspirations of for work, plus barriers/enablers \\
\hline & Anything on youth Not in Education Employment or Training \\
\hline & Variation by gender, income, location, education level etc. \\
\hline & Levels of education and training \\
\hline & Comment on data quality \\
\hline & Other \\
\hline Climate change & Impact in rural areas \\
\hline livelihoods (may & Impact in urban areas \\
\hline region) & Changes in livelihoods in response to climate change \\
\hline & Evidence for migration in response to climate change \\
\hline & Disruptions to education, training, or apprenticeships \\
\hline & Climate change and marriage and child bearing \\
\hline & Climate change and conflict \\
\hline & Young people affected differently to other groups \\
\hline
\end{tabular}




\begin{tabular}{|l|l|}
\hline \multirow{y}{*}{ Responses } & Influence of gender, age, income, location on youth impacts \\
\cline { 2 - 3 } & Identification of gaps in the literature \\
\cline { 2 - 3 } & Other \\
\cline { 2 - 3 } & If and how young people adapting \\
\cline { 2 - 3 } & If young people are mitigating climate change \\
\cline { 2 - 3 } & Young people's involvement in policy responses \\
\cline { 2 - 3 } & The change young people want to see \\
\cline { 2 - 3 } & Identification of gaps in the literature \\
\hline & Other \\
\hline
\end{tabular}

Table 3. Criteria for systematic literature search

\section{Significance of the review}

In addition to contributing to the academic discourse and knowledge gap on this subject, this review was also aimed to inform policy making and programme implementation by stakeholders at various levels in Uganda and other countries in Eastern and Central Africa. At the local level, the review seeks to inform young people about livelihoods opportunities and how they respond to climate change. For government (local and national), the recommendations of this review should inform the design and implementation of youth livelihoods and climate change mitigation and adaptation interventions. Policy makers at the regional and international levels can also draw upon the findings of the review aims to engage young people in seeking solutions to unemployment and other impacts of climate change.

\section{Limitations}

Despite more systematic and rigorous reviews having great advantages over traditional reviews, there are limitations to be considered. First, by selecting only English language academic literature, this study excludes literature published in other languages, especially French. Although there is more linguistic diversity than just the colonial languages, French is still the official or dominant language in the Central African countries of Burundi, Cameroon, Central African Republic, Chad, 
Democratic Republic of Congo, Gabon, Republic of Congo, and Rwanda. Secondly, much as systematic analysis of the literature limits bias and increases transparency of the process, the thematic analysis of evidence leaves open a certain level of interpretation (Marijn, 2018). The researchers limited this bias by reporting on only their analysis of the theme, and working as a team to identify, source and review papers.

\section{Characterizing the literature}

The general characteristics of the literature reviewed for this paper are as follows. Of the 62 articles that met the inclusion criteria, 47 were single-case studies; with a few studies comparing multiple cases of youth livelihoods and climate change adaptation and mitigation strategies. A total of 11 articles did not report on the study design and other vital aspects of the methodology (such as case selection, sample size and analysis procedures). Surveys (32), mixed methods (19), document study (8) and focus group discussions (3) were the most widely used methods of data collection. For data analysis, most of them refer to the use of statistical techniques such as correlation and chi-square tests (51) while the rest (11) refer to the use of qualitative techniques such as thematic coding and social network analysis. 


\section{Findings}

Reviewing the state of knowledge around how young people intersect with climate change in Uganda, and other Eastern and Central African countries, we first discuss the nexus between climate change, youth demographics, and youth livelihoods. We then present the youth-specific impacts of climate change, and responses to the challenges faced by young people in dealing with climate change.

\section{Features of climate change}

The environmental changes associated with climate change in Africa are diverse, yet understandings of both current and longer-term trends are hampered by a lack of data (IPCC, 2021; Toulmin, 2009). Nonetheless, it is established that Africa is expected to warm during the $21^{\text {st }}$ century and there has already been an observed increase in the hot extremes in South East and North East Africa (ibid). Summarizing the literature, Nyasimi et al; (2018) describe how "Climate change and variability is exacerbating the drying up of already arid zones in Africa, decreasing volumes of inland surface and subsurface water, causing shifts in cropping and farming systems, changes in pests and disease dynamics, and creating competing demands for shrinking natural resources that have the potential for creating bilateral and multilateral conflicts." (p.172). These observed environmental changes are decidedly uneven, both spatially and temporally. For instance, in the period 1960-2010, Uganda has experienced a $0.28^{\circ} \mathrm{C}$ per decade temperature increase. Disaggregating these averages by calendar month shows a decade long average increase of $0.37^{\circ} \mathrm{C}$ for January and February (NAPA, cited in Opio, 2019). Looking ahead, it is expected that Uganda will experience a further $2^{\circ} \mathrm{C}$ of warming during the next 50 years (Nyasimi et al., 2016). These averages hide larger local increases at certain times, with some areas impacted more acutely than others.

Rainfall volume has already decreased in the region, and the next 50 years are expected to lead to further reductions in annual rainfall in Uganda (Nyasimi et al., 2016; Opio, 2019). As with temperature change, the uneven and unpredictable nature of changes to precipitation presents a challenge, alongside the changing annual averages. The start and end of rainy seasons has become increasingly erratic, with particularly heavy and sometimes violent rainfall events being recorded. These new rainfall patterns have led to more flooding and landslides, especially in the Mount Elgon region of Eastern Uganda (Osuret et al., 2016; Opio, 2019). Alongside times of intense and destructive precipitation is another form of disruption caused by insufficient rain. In Mbale, Eastern Uganda, $63 \%$ of people surveyed had been impacted by both drought and erratic rainfall (Oxfam 2017, in Oriangi et al., 2020). Some districts, specifically Kiruhura and Isingiro, now report frequent and severe droughts (Nagasha et al., 2019). Furthermore, significant bodies of water have also been observed to have shrunk, including lowering water levels of both 
Lake Victoria and the River Nile which has its source in Uganda (Muhumuza et al. 2011).

To capture something of the magnitude of the impacts of climate change, four of every five natural disasters are linked to climate change and severe weather (Chirambo, 2017). While the physical changes brought by climate change are of great significance to natural systems and other forms of life irrespective of their human impacts, the remainder of this paper 'humanizes' climate change (after Dorling and Barford, 2006) by making sense of how long term environmental change intersects with young people's livelihoods, understandings, and to review youth and policy-level responses.

\section{Youth demographics and definitions}

The global youth population is projected to peak at 1.5 billion in 2035 and it will increase most rapidly in Sub-Saharan Africa (SSA) and South East Asia (by 26 percent and 20 percent respectively between 2005 and 2035) [see IPCC, 2021]. The Food and Agricultural Organization (FAO) estimates that around 55 percent of young people reside in rural areas, but this figure is as high as 70 percent in Sub Saharan Africa and South Asia. In Sub Saharan Africa, young people aged 15-24 comprise 36 percent of the entire labour force, 33 percent in the Near East and North Africa, and 29 percent in South Asia.

Widely perceived as an individual's 'before adulthood' (Oxford Online Dictionary), but also as a time of being as well as becoming (Barford et al., 2021 after Uprichard, 2008), youth is defined and understood differently between countries. Only nine publications included in our literature review conceptualize youth; albeit with considerable variation in the definitions of 'youth' between Central and Eastern African countries. In Uganda, a youth is for instance-by Constitutional definitionan individual below 35 years of age (Uganda Constitution, 1995), although the Uganda Youth Policy defines a youth as a person who is aged between 18-30 years (UBOS, 2017). On the other hand, the Kenyan government defines youth as a person aged over 18 but not yet 35 years old (Kenya Constitution, 2010). On its part, Ethiopia defines youth as individuals aged between 15-29 (Ethiopian National Youth Policy, 2012). Overall, there is minimal focus on the conceptualization of youth in the literature reviewed.

\section{Youth livelihoods}

Even before the impacts of the climate emergency really began to set in, there was another crisis in full swing - one of inequality, widespread poor sanitation, curable diseases allowed to run rampant, and poverty (Dorling \& Barford, 2006). Within this, the lack of good jobs and the prevalence of working poverty, especially amongst 
young people, hampers resilience and security (O'Higgins, 2017; Barford et al., 2020; Fox et al., 2020). Findings of this review shows that most of the literature on youth livelihoods in Eastern and Central Africa largely focuses on 'the capabilities, assets (both material and social resources) and activities required for a means of living' (Bennell, 2007). Seven (7) articles conceptualized youth livelihoods under the framework that divides livelihood assets into 6 types: natural assets, physical assets, financial assets, human assets, social assets and cultural assets. A total of 19 articles that report on livelihoods for young people in Uganda, the Central African Republic, Kenya and Rwanda highlight agriculture as the most important source of livelihood for most young people in the region. Fourteen (14) others allude to the fact that a significant number of young people are employed in the formal sector and earn salaries and wages on a regular basis, while six (6) demonstrate that many young people eke out a living from informal sector activities due to lack of education, assets, investment capital and skills, among other reasons. Other articles emphasize that it is largely young people who are dependent on the informal sector that are highly vulnerable to the impacts of climate change on their livelihoods (Okalebo, 2015). There is also grey literature showing that young people rely on a host of small-scale diversified wealth creation activities to improve household incomes including in major trading centres (Barford \& Coombe, 2019).

Other recent studies show a growing sense of pessimism about the situation of youth livelihoods and the scope for improving their wellbeing amidst the ever-escalating impacts of climate change (see Care International, 2016; Hardi, 2017; Lee et al., 2020). Given that 'peak' youth comprise the majority of the total population in Eastern and Central Africa, the future looks potentially bleak amidst limited livelihood opportunities (O'Higgins, 2017; Barford et al., 2020; Cieslik et al., 2021). The situation is worsened by the limited political will to fully implement climate change undertakings agreed to by most countries during the 2015 Paris Climate Agreement (UNFCCC, 2016). Underemployment is high in all the Central and Eastern African countries, especially for young people. Low incomes render communities and families particularly vulnerable, hence their ability to cope with climate related shocks is constrained yet adaptation to a changing climate is crucial (Jasmina, 2019). The literature reviewed presents a range of youth livelihood strategies as they struggle to overcome unpredictable and increasingly extreme environmental conditions.

\section{Youth-climate change interactions}

Context matters. Young leaders and the academic literature alike acknowledge how climate change is not simply an environmental problem, but rather intersects with social, economic and political issues. We now review the types of impact, young people's adaptive and mitigative responses to these impacts, and how young people's responses to climate change are constrained. Young people's solutions to the challenge of climate change are discussed in numerous papers in this review 
(Frappart et al., 2016; Garg \& Lal, 2018; Hermans \& Korhonen, 2017; Hestness et al., 2016; Jackson \& Pang, 2017; Karpudewan et al., 2015; Puttick et al., 2015; Scott-Parker \& Kumar, 2018; Wilks \& Harris, 2016). Curiously, African youth activism has received less attention to date.

Overall, Africa is expected to be especially negatively affected by climate change (UNEP, no date). With three quarters of the African population under the age of 35 this means that numerically young Africans will be highly impacted. The literature describes key pathways of these detrimental impacts through direct impacts on physical health, mental health, forced migration and reduced capacity to make a living leading to increases in poverty. Physical health impacts include drowning in floods, especially for those who cannot swim, death or injury in landslides, heat stress which particularly impacts agricultural and construction workers and leads to a slower pace of work, and increased disease (ILO, 2019). The type of changes projected are also more disruptive than conducive to improving growing conditions (Toulmin, 2009, p.15). There are several ways in which climate change impacts young people in Central and Eastern Africa featured in the literature reviewed. Loss of livelihoods, deaths, displacement and social misery are featured as the main impacts of climate change on youth in the literature reviewed. Over half of the articles reviewed on this theme indicate that the impact is greater in rural, mountainous areas where landslides and floods have become a perennial phenomenon in many countries.

Other notable impacts documented in the literature include: rising lake water levels (Mugyenyi et.al., 2020), torrential downpours causing floods in cities and towns and rising temperatures (Klara \& Hajdu, 2017; Oriangi et.al., 2020; Tenywa et al., 2016; Nagasha et.al., 2019). While being on the receiving end of the effects of climate change presents young people as one of the groups of individuals who have fallen victim to human-driven environmental changes, their response to local, national and global efforts to mitigate its effect on society could well make them part of the solution. Overall the literature review presents young people as 'victims and solution providers' in the climate change and development equation (Osuret, et al., 2016; Oriangi et al., 2020).

In terms of young people's reactions and responses to climate change, the literature focuses on the benefits of mitigation and adaptation among vulnerable communities such as young people (NEJAC, 2018). There is evidence of diversification and flexibility in livelihood practices, with some young people opting for sports betting and other forms of gambling (Njeri, 2017; Bruno \& Kizito, 2018; Ramadhani, 2019), though this also offers little certainty or income security. While sugarcane and sugar yields fluctuate with extreme climate events (drought and tropical cyclones) in most countries in the region (Duli, 2015), a number of young people have diversified their cultivation of the crop (Salami et. al; 2018). In Uganda and neighbouring countries, 
some young people have found diverse alternatives to growing sugar cane such as apiary, poultry keeping and zero-grazing (Mugyenyi et al, 2020).

Migration is a key part of the adaptive toolkit for young people. Research in some African countries has shown that cities offer opportunities for off-farm work, near to rural areas, which can increase people's resilience (World Bank, 2018). A mix of 'push' factors, including climate change-induced pressures, poverty-level agricultural incomes, and shrinking plot sizes, are leading young people to seek alternative livelihoods to agriculture. In Rwanda, young people-both migrants and host communities members-have shown great leadership in tackling climate change issues through Choose Yourself, a youth-led Non-Governmental Organisation (NGO) that empowers young migrant women to navigate the job market and avoid genderbased exploitation. This, through varying forms of capacity building, has also provided a range of opportunities to promote environmental conservation (USAID, 2019). Much as the literature reviewed points to a host of mitigation and adaptation strategies by young people in dealing with the impacts of climate change, it also features a number of challenges faced in dealing with the phenomenon.

Elsewhere, the literature presents young people as a key pillar in the sustainable management of natural resources in some countries (Kwado et al, 2018; Thew, 2018). In most cases, youth mobilization activities occur through numerous networks that are orchestrated by government, political parties, civil society groups, grassroots networks, and/or community associations. Some common examples of these networks are include; eco-clubs organized by NGOs, youth groups within Forest Community Associations, school-based youth councils or grassroots networks animated by autonomous youth groups and school-based youth councils (Kurt, 2015). Many of these networks have diverse mandates that often include environmental issues, prevention of domestic violence, watchdog activities or extracurricular activities, among others. While school-based youth councils are extensive and include an environmental component, these are generally nonoperational in most schools due mostly to a lack of leadership. In cases where they are active, they are often teacher-directed rather than student-led (Masuda, 2019).

Young people engaged in climate change adaptation and mitigation interventions also face a host of institutional, structural and financial obstacles (Amponsem et. al., 2019). This involves limited government support in the form of subsidies to support alternative sources of livelihood such as apiary or zero grazing, high levels of corruption and embezzlement of funds provided for them to start climate resilient income generating projects and limited access to information about resilience and adaptive capacity to climate change.

The literature further shows that the youth also face challenges in accessing training opportunities in various developmental activities of which climate change and environmental issues are central. With respect to gender, young people face varying forms of discrimination in access, ownership and utilization of resources and 
technologies that would enable them deal with the effects of climate change. The situation is aggravated by the high levels of poverty. Uganda and Kenya heavily rely on rain-fed agriculture which is in turn greatly affected by the vagaries of climate change forces (Katharine et al, 2020; Chebet, 2017). Those who have succeeded in breaking the gender and poverty chains in their attempt to combat the climate change bottlenecks have also come face to face with the failure-by policy makersto integrate climate change and environmental issues into the educational curriculum. This is especially relevant for the transfer and integration of indigenous knowledge into modern mitigation and adaptation practices.

There was a tendency for the literature to find that, similar to participants' knowledge of the causes and impacts of climate change, youth solutions to climate change were often somewhat superficial and featured misconceptions. The most recognized solutions were planting trees (Kilinc, 2018) and reducing pollution (Garg \& Lal, 2016) particularly from factories (Daniel et al., 2016), and changing transportation systems (Bofferding \& Kloser, 2015). However, young people's understandings of causes and effects were incomplete. One example is that the time lag involved in planting trees and storing carbon was not appreciated (Tenywa et al, 2017), and participants could not explain the mechanisms by which reducing pollution or planting trees would reduce global warming (Frappart et al., 2016). The literature reviewed also proposes the reduction in street litter or river pollution and the use of nuclear power in mitigating the impact of climate change (Hestness et al., 2016). A study conducted in the Karamoja region of Uganda showed that most people who perceived changes to the climate did not take any action to adapt, typically because they did not know how to (Chebet, 2017). Thus the literature flags limited understandings of the science of climate change thereby hampering the responses to the impact of the phenomenon.

\section{Youth-led climate activism}

Little research into youth climate activism in Eastern and Central Africa was found during this literature review process. In contrast, there is growing literature on climate activism in the higher income countries (e.g. Kleres and Wettergren, 2017; Nairn, 2019). Since 2019 climate activism has become the most high profile part of the youth response to climate change. In Uganda, young women have become key players organising school strikes as part of the Fridays for Future global movement and engaging in practical activities to bring about more immediate change, such as collecting plastic rubbish from the streets and waterways (Chebet, 2017). To share some insight into the motivations and aspirations, Nakabuye Hilda Flavia, founder of the Fridays for Future Uganda emphasises the urgency and scale of climate change, how activism includes educating and motivating young people as well as pressuring decision makers. She also highlights the view that climate activism can be a lonely experience without community support. Nakabuye also describes the emotional 
exhaustion and determination associated with challenging the status quo in the film 'Dear Future Children' (2021).

"We are facing a climate emergency; we need unprecedented global action because we are running out of time. The only way to protect our generations future is by standing up and speaking out. We are the first generation to know what we are doing and the last one to be able to save it."

"Despite being directly affected by the consequences of climate change, most young people in my country are not aware of the climate breakdown we are facing because climate change is not taught in schools. I engage with youth during my strikes and urge them to join me as we demand for climate action."

"One of the challenges I face is the slow inaction and response from public, our governments and policy makers in my country towards climate action. Sometimes the community does not support me in my strikes because I disagree with some of their activities such as disposal of waste in lakes and rivers, car washing on lake shores."

\section{Nakabuye Hilda Flavia, 2019}

The literature also shows that the law plays a double-edged role in climate change activism. Youth-led responses in Uganda, have for instance relied on the legal system to take national governments to court on the basis that climate change is compromising their constitutional and human rights (Hewitt and Gubbay, 2020). Although the 2012 case of Mbabazi and Others v The Attorney General and National Environmental Management Authority (Civil Suit No. 283 of 2012) was filed by the NGO Green watch, the case was supported both legally and financially from outside of Uganda. Evidence was heard in May 2019 (Adelman, 2021); yet "the matter is still pending" (Green watch, 2021, no page number). Given the level of vulnerability to climate change-induced harm, there have been surprisingly few litigations taking place in Africa (Adelman, 2021), which could in part be due to the slow progress of such cases within the courts. On the other hand, the law is also used to constrain activists. In September 2020, 20 young activists were arrested during a climate strike which aimed specifically to highlight threats of felling the Bugoma Forest. The police attributed these arrests to a lack of formal permissions to protest (Wetaya, 2020).

Youth-led climate activism, which has rapidly scaled over the past 5 years, is now increasingly recognised as a global phenomenon, with young people's voices increasingly welcomed into high level discussions. The contentions now are to ensure that the voices of the most impacted are heard, and whether their messages are acted upon (see Barford, 2021; Barford and Nyiraneza, 2021). 


\section{Policy responses}

While young people are working to adapt to and mitigate climate change in their own lives, they are faced with the failure of most of their leadership to formulate and implement policies that ensure sustainable development at both local and continental levels through the integration of a youth and gender perspective (Shakespeare et. al., 2017). Policy responses to climate change related disruptions exist at the supranational, regional, national and local levels. Across Asia and Africa, there is an overall trend of policy interventions to support climate adaptation at the national level while lower levels of government have played a minimal role in recent years (Ford et al., 2015). Adaptation funds from the United Nations Climate Change (UNFCCC) have been disbursed to National Adaptation Programmes of Action. Agenda 2063 of the African Union Commission (2015) offers high level commitments to support young people and to address climate change. These statements include the following commitments:

54. The youth of Africa shall be socially, economically and politically empowered through the full implementation of the African Youth Charter.

56. All forms of systemic inequalities, exploitation, marginalization and discrimination of young people will be eliminated and youth issues mainstreamed in all development agendas.

57. Youth unemployment will be eliminated, and Africa's youth guaranteed full access to education, training, skills and technology, health services, jobs and economic opportunities, recreational and cultural activities as well as financial means and all necessary resources to allow them to realize their full potential.

58. Young African men and women will be the path breakers of the African knowledge society and will contribute significantly to innovation and entrepreneurship. The creativity, energy and innovation of Africa's youth shall be the driving force behind the continent's political, social, cultural and economic transformation.

(African Union Commission, 2015, p.9)

With respect to climate change, the African Union Commission (2015) discusses the importance of "prioritizing adaptation ... to ensure implementation of actions for the survival of the most vulnerable populations" (p.3-4), and notes the importance of targeting women and young people in climate change programmes (p.16). 
There are country-specific climate change interventions for young people in some countries in the region. The Ugandan government enacted the National Youth Policy (2001) that among other specific interventions provided for the Youth Livelihood Programme (YLP) and Youth Livelihood Fund (YLF); created to provide funding and other support to small enterprises led by youth (NYP, 2001). Largely aimed to support small business development, job creation and add value to the core youth livelihood activities such as maize processing, livestock feed production and other non-farm livelihood activities; the policy was considered a panacea to most challenges that result from the impact of climate change on young people. Even if some groups of young people have variously benefitted from the YLP/YLF programme, the multiplier effect of its interventions is yet to be felt nationwide. Its implementation has also been dogged by claims of corruption and marginalization of some youth Savings and Credit Cooperatives (SACCOs) groups in some parts of the country.

\section{Discussion}

Overall, the studies published in the past five years demonstrate that climate change and youth livelihoods are closely interwoven. The current climate shocks and stresses documented across the region greatly impinge on the well-being of young people through various mechanisms. By and large, young people's lives tend to be directly affected by climate change, albeit in diverse ways. Climate change does not occur in a vacuum, instead interacting with other trends, challenges and crises. The already fragile livelihood strategies - adopted due to a lack of other opportunities and a structural deficit of decent work - leave young people exposed to greater risks of disruption. The combination of insufficient jobs, widespread reliance of agriculture, and working poverty means that many of the cornerstones (savings, reliable income stream, and certainty of finding work) of economic security are absent.

While the impacts of climate change have been severely felt by young people, these are uneven amongst young people. For instance, desertification in South Sudan and the Democratic Republic of Congo has led to an influx of climate change refugees into Rwanda and Uganda, resulting in children and young people living in urban camps without adequate education and health care and subject to the resultant spread of disease (Kiaras \& Anderson-Nathe, 2018). As with other vulnerable and marginalized communities, climate change impacts youth livelihoods in specific ways, contingent upon their roles and responsibilities at the household and community levels (IPCC, 2021). Faced with other challenges such as living with disabilities, lack of credit, limited education and employment opportunities and limited involvement in political and household decision-making processes, some young people have resorted to the illegal exploitation of timber and other natural resources for a living thereby exacerbating the climate change phenomenon in their settings. Cultural norms related to gender limit the capacity of young women to make 
quick influential decisions about their livelihoods, such as whether to move to safer grounds in disaster situations (Adger et al., 2018).

Most studies reviewed document disproportionate harm to young people since they are more likely to be affected by poor health or death, damage to homes, workplaces and essential infrastructure, limited or non-existent public services, and the unavailability or unaffordability of water, food and other consumption items. The literature reviewed here suggests that much as there is well documented impact of climate change on young people, this group of individuals do-like most socially excluded groups-have limited opportunities to participate and influence the allocation of resources to ameliorate the impacts of climate change (UN 2016a).

A key conclusion from the literature on this subject is that investing in strategies to address vulnerability and often gendered socio-cultural attitudes, such as encouraging young people-especially young women—to learn skills such as swimming and tree climbing, can help people to survive during floods (Hunter et al, 2020). Similarly, the implementation of youth empowerment programmes to enable young people to acquire capital to venture into self-employment projects (notably in the service sector) instead of depending on natural resources for their livelihoods can have great impact (Arora-Jonsson, 2018). This is why it is even more critical to involve young people in efforts to integrate climate change into development planning -notably policy-making, budgeting and implementation processes at the national, sector and subnational levels as it is being done in Uganda (NPA, 2020).

In respect to solutions to the climate change challenges faced by young people in the region, the literature shows that many are involved in small-scale climate resilience practices aimed to enable young people to cope with the phenomenon. In Uganda, the Advocates Coalition for Development and Environment (ACODE) has been promoting inter-district learning visits for the youth in various parts of the country to enable those involved in agriculture learn and adopt climate resilient agricultural practices such as small scale irrigation, use of compost manure to improve soil fertility, use of biogas and maximize water resources (Mugyenyi et.al., 2020). On its part, the East African Community (EAC) launched the East Africa Youth Inclusion Program (EAYIP); a five-year program (2016 -2021) aimed to improve the livelihoods of 25,000 economically disadvantaged young men and women (aged 15-24 years) in Uganda and Tanzania by creating 'green jobs' and entrepreneurship opportunities to offset the impact of climate change on their lives. In Uganda, the program is being implemented by providing young people with a proposition that involves value addition to agricultural products while promoting recycling of what was previously considered waste material into renewable energy resources (MOGLSD, 2020). 
Overall, the key recommendations that emerged from this review show that addressing the climate change challenges facing the youth requires:

- Grading access roads to control flooding;

- Increasing funding to the Village Savings and Loans Associations (VSLAs);

- Training the youth in alternative livelihoods such as bakery, carpentry, auto mechanics and masonry.

- Implementing gender sensitive policies since both boys and girls are involved in the various sources of livelihood.

- Implementing the "nothing for us without us" policy by involving the youth in decision making and programming for themselves at all levels

- Creating new synergies between and across communities through climate change educational, awareness-raising and behavioural change campaigns;

- Involving the youth in climate change projects within different national and international organisations such as the United Nations Climate Change Conference of Parties (COPs).

\section{Conclusion}

The aim of this systematic review is to report on (1) the diverse lives and livelihood strategies of young people in rural and urban settings in Uganda and neighbouring countries, (2) how climate change impacts upon their lives and livelihoods, and (3) solutions to these challenges. The review was largely qualitative and focuses on existing literature from which it is not necessarily possible to generalize its findings. Although certainly not exclusive, the 64 articles reviewed largely represent the recent literature that exists on this subject. The focus on literature published between 2015 and 2020 is also an important factor as it potentially provides the latest findings on the subject in the study region. With our focus on livelihoods opportunities and the impacts and solutions to climate change challenges facing young people, this paper contributes to knowledge through a review of the growing body of literature on this subject, clarifying key themes, and allowing the identification of research gaps.

This review identifies certain gaps in knowledge and understanding. In particular, understandings of pathways to adaptation to climate change are still patchy (Ford et al., 2015), and even understanding the nature of this change is limited by a lack of long term records for Africa (Toulmin, 2009; IPCC, 2021). In terms of the human geography of climate change, it has been recommended that more research is done to better understand climate change and the impact upon young people (Jevanic Henry, in Barford and Cieslik, 2019). New research should seek to produce more longitudinal studies to achieve a better sense of change over time (Rachel Proefke, in Barford and Cieslik, 2019), especially in light of the increasing levels of disruption which are faced by a growing youth population. Youth climate activism in Africa so far has received limited research. The impacts of climate change on young people's mental well-being have been largely overlooked to date. Supporting young people in 
relation to climate change will require more youth focused research and authentic youth engagement in national and international policy responses.

Much as the literature reviewed here highlights how young people are at the frontlines in climate action, as evidenced by the millions of young people who raised their voices in protests around the world in a massive display to demand urgent action on climate change (NPR, 2019). The struggle for climate justice is far from over. There is need for young people to not only continue to exert pressure on their national governments for more inclusion in climate change policy formulation and implementation strategies but also to build momentum for an equitable and sustainable global environmental management system during the annual United Nations Convention on the Climate Change Conference of Parties (COPs) held annually on various continents. Like for the other vulnerable groups of individuals, the youth voice on climate change injustices and the need for a just transition towards a low carbon society needs to be heard within and beyond the confines of the conference halls in order to result in tangible action against the climate crisis.

\section{Funding}

This publication was made possible thanks to funding from the British Academy Youth Futures Programme, for the research project 'Peak Youth, Climate Change and the Role of Young People in Seizing their Future'. The grant is held by researchers working between the University of Cambridge (UK), Makerere University (Uganda), and Restless Development Uganda.

\section{Conflict of interest}

The authors have declared no conflicts of interest for this paper.

\section{Author contributions}

Anthony Mugeere: Conceptualization; methodology; analysis; writing original draft. Anna Barford: Securing funding; Conceptualization; Search for literature resources; Writing original draft; and Editing. Paul Magimbi: Support to the search for literature resources; and Reviewing literature. 


\section{References}

Adelman, James S. (2021) Climate change litigation in the African system. In: Alogna, Ivano and Bakker, Christine and Gauci, Jean-Pierre, (eds.) Climate Change Litigation : Global Perspective. Nijhoff : Brill. ISBN 9789004447608

Adger, W.N., J.M. Pulhin, J. Barnett, G.D. Dabelko, G.K. Hovelsrud, M. Levy, Ú. Oswald Spring, and C.H. Vogel. (2014). Human security. In: Climate Change 2014: Impacts, Adaptation, and Vulnerability. Part A: Global andSectoral Aspects. Contribution of Working Group II to the Fifth Assessment Report of the Intergovernmental Panel on Climate Change[Field, C.B., V.R. Barros, D.J. Dokken, K.J. Mach, M.D. Mastrandrea, T.E. Bilir,M. Chatterjee, K.L. Ebi, Y.O. Estrada, R.C. Genova, B. Girma, E.S. Kissel, A.N. Levy, S. MacCracken, P.R. Mastrandrea, and L.L. White (eds.)]. Cambridge University Press, Cambridge, United Kingdom and New York, NY, USA, pp. 755-791.

African Union Commission. 2015. Agenda 2063: the Africa we want. https://www.un.org/en/africa/osaa/pdf/au/agenda2063.pdf

Amponsem J., D. Doshi, A. I. Salazar Toledo, L. Schudel \& S. Delali-Kemeh. (2019). Adapt for our Future: Youth and Climate Change Adaptation. Rotterdam and Washington, DC. Available online at www.gca.org

Arora-Jonsson, S \& Westholm, L. (2018). Defining solutions, finding problems: Deforestation, gender, and REDD+ in Burkina Faso Conservation and Society, 13 (2) (2015), p. 189.

Barford, A., Proefke, R., Mugeere, A., and Stocking, B. forthcoming. COP26 Briefing on Young People and Climate Change. British Academy COP26 Briefing Series. https://www.thebritishacademy.ac.uk/projects/knowledge-frontiers-cop26-briefings/

Barford, A., Coombe, R. and Proefke, R., 2021. Against the odds: young people's high aspirations and societal contributions amid a decent work shortage. Geoforum. 162-172

Barford, A., Coombe, R., and Proefke, R. (2020). Youth experiences of the decent work deficit. Geography, 60-68. https://www.repository.cam.ac.uk/handle/1810/305784

Barford, A. and Cieslik, K. (2019). Making A Living: A Youth Employment Agenda. Published by Murray Edwards College, in July 2019. CC BY Creative Commons license. DOI:

10.17863/CAM. 41570

https://www.repository.cam.ac.uk/handle/1810/294839 
Barford, A. and Coombe, R. (2019). Getting by: young people's working lives. Published by Murray Edwards College, in April 2019. CC BY Creative Commons license.

10.17863/CAM.39460

https://www.repository.cam.ac.uk/handle/1810/292310

Barford, A. and Nyiraneza, M. (2021). Young activists are tired of their views on the climate crisis being ignored. Opinion piece, The Independent. 11.8.2021. https://www.independent.co.uk/climate-change/opinion/climate-crisis-uganda-youngactivists-cop26-b1896067.html

Bennell, P.S. (2007). Promoting Livelihood Opportunities for Rural Youth, Knowledge and Skills for Development, Geneva, sILO.

Bapna M, Brandon C, Chan C, Patwardhan A, Dickson B. 2019. Adapt Now: A Global Call For Leadership On Climate Resilience. Rotterdam: Global Center on Adaptation. Available at: https://cdn.gca.org/assets/2019-09/GlobalCommission Report_FINAL.pdf 40. Thornton PK, Kristjanson

Bofferding, L. \& Kloser, M. (2015). Middle and high school students' conceptions of climate change mitigation and adaptation strategies. Environmental Education Research 21(2) Follow journal DOI: 10.1080/13504622.2014.888401

Bruno, Y., \& Kizito, S. (2018). Gambling and Mobile Money Payments: A Case Study of Sports Betting in Uganda. School of Economics, College of Business and Management Sciences. Makerere University, Kampala, Uganda.

Caffrey, P., Finan, T., Trzaska, S., Miller, D., Laker-Ojok, R. and Huston, S., 2013. Uganda climate change vulnerability assessment report. USAID African and Latin American Resilience to Climate Change (ARCC) August. http://muccri.mak.ac.ug/sites/default/files/Publications/Vulnerability\%20Assessment \%20in\%20Uganda-Exec\%20Summary.pdf

Care International. (2016). Annual Report. Retrieved on December 27, 2020 from www.care-international.org

Chebet, M. (2017); New Study Finds Worrying Climate Trend In Karamoja Over Last 35 Years, Minsitry of Water and Environment, Kampala, Uganda.

Chirambo, D. (2017). Enhancing climate change resilience through microfinance: Redefining the climate finance paradigm to promote inclusive growth in Africa. Journal of Developing Societies 33, 150-173 (2017). DOI: $10.1177 / 0169796 \times 17692474$

Christine, J., Kyazze, F., Jesse, N., Sharmind, N., Kinyangi, J., Zougmore, J., Pramod, A., Gopal, B., Moushumi, C., Marja-Liisa., Tapio-Bistrom., Sibyl, N., \& Patti, 
K., (2016). Understanding gender dimensions of agriculture and climate change in smallholder farming communities, Climate and Development, 8: (2), 133-144, DOI: 10.1080/17565529.2015.1050978.

Cieslik, K., Barford, A. and Vira, B., 2021. Young people not in Employment, Education or Training (NEET) in Sub-Saharan Africa: Sustainable Development Target 8.6 missed and reset. Journal of Youth Studies, p.1-22. doi:10.1080/13676261.2021.1939287.

Christensen, J.H., Larsen, M.A.D., Christensen, O.B. (2017). Robustness of European climate projections from dynamical downscaling. Clim Dyn 53, 4857-4869 (2019). https://doi.org/10.1007/s00382-019-04831-z

Clionadh, R., Hyun, J., \& Choi b., \& Dominic, Kniveton. (2015). The devil is in the details: An investigation of the relationships between conflict, food price and climate across Africa. Global Environmental Change, 32 (2015) 187-199.

Daniel M., Clare, Heaviside., Sotiris, V. Chris, H., Giacomo, M., Benoit, P., Guillod,, P., Frumhoff, A., David, W., \& Myles. A. (2016). Attributing human mortality during extreme heat waves to anthropogenic climate change. Environ. Res. Lett. 11074006

Davis, J. \& Gephart, K. (2018). Meeting future food demand with current agricultural resources Global Environ. Change, 39 (2016), pp. 125-132, 10.1016/j.gloenvcha.2016.05.004

Dear Future Children. 2021. Documentary film. https://dearfuturechildren.com/

Dorling, D., Barford, A. and Wheeler, B. 2007. Health impacts of an environmental disaster. Environmental Research Letters, 2(4) 1-11 https://www.geog.ox.ac.uk/research/transformations/gis/papers/dannydorling public ation id1829.pdf

Dorling, D. and Barford, A. 2006. Humanising Geography. Geography, Autumn 2006, 187-197

https://www.geog.ox.ac.uk/research/transformations/gis/papers/dannydorling public ation id0893.pdf

Duli, Z. (2015). Climate Change and Sugarcane Production: Potential Impact and Mitigation Strategies. International Journal of Agronomy. I https://doi.org/10.1155/2015/547386

Dunning, C. M., Black, E., \& Allan, R. P. (2018). Later wet seasons with more intense rainfall over Africa under future climate change. Journal of Climate, 31(23), 9719-9738. 
Ethiopia. (2012). Youth Policy Factsheet: Ethiopia http://www.youthpolicy.org/factsheets/country/ethiopia/

FAO (Food and Agricultural Organization of the United Nations). 2021. FAO Regional Office for Africa. Accessed on 8.8.2021 from: http://www.fao.org/africa/regional-office/en/

Fereday J \& Muir-Cochrane E. (2006) Demonstrating rigor using thematic analysis: a hybrid approach of inductive and deductive coding and theme development. Int $J$ Qual Methods 5,80-92.

Ford, J. D. \& Pearce K. (2015). Coverage and framing of climate change adaptation in the media: A review of influential North American newspapers during 1993-2013. Environmental Science \& doi:10.1016/j.envsci.2014.12.003.

Fox, L., Mader, P., Sumberg, J., Flynn, J. and Oosterom, M., 2020. Africa's 'youth employment' crisis is actually a 'missing jobs' crisis. Brookings Institute, Africa portal. Published 18/10/2020. https://www.africaportal.org/publications/africas-youthemployment-crisis-is-actually-a-missing-jobs-crisis/

Frappart, S., Moine, M., Jmel, S., \& Megalakaki, O. (2016). Exploring French adolescents' and adults' comprehension of the greenhouse effect. Environmental Education Research, 24(3), 1-28.

Garg, A., \& Lal, P. (2018). Perception of causes, consequences and solutions to global warming among school children in Delhi. Indian Journal of Public Health Research and Development, 4(3), 27-32.

Godfrey, S. and Tunhuma, F.A., The Climate Crisis: Climate Change Impacts, Trends and Vulnerabilities of Children in Sub Saharan Africa, United Nations Children's Fund Eastern and Southern Africa Regional Office, Nairobi, September 2020

Gough, D, Sandy, O. \& James T. (2017). An Introduction to Systematic Reviews. Systematic Reviews. London: SAGE, 2017.

Hardi, S. (2017). Youth Understanding of Climate: Towards a theory of social adaptation to climate change in Africa. MA Dissertation. University of London, UK.

Hermans, M., \& Korhonen, J. (2017). Ninth graders and climate change: Attitudes towards consequences, views on mitigation, and predictors of willingness to act. International Research in Geographical and Environmental Education, 26(3), 223239. 
Hestness, E., McGinnis, J. R., \& Breslyn, W. (2016). Examining the relationship between middle school students' sociocultural participation and their ideas about climate change. Environmental Education Research, 25(6), 1-13.

Hewitt, S. and Gubbay, I. (2020). 'The Latest Court Challenge in a Steady Line of Leading Youth-Led Climate Case's. Lexology, Published on 22.4.2020. Accessed on 28.2.2021 from: https://www.hausfeld.com/print/1449

Hunter, D. Wenhui J., \& Jenna,Ruddock. (2020). The Paris Agreement and Global Climate Litigation after the Trump Withdrawal, 34 Md. J. Int'l L. 22. Available at: https://digitalcommons.law.umaryland.edu/mjil/vol34/iss $1 / 9$

International Labour Organisation (ILO), 2020. Preventing exclusion from the labour market: tackling the COVID-19 youth employment crisis. https://www.ilo.org/wcmsp5/groups/public/--ed emp/documents/publication/wcms 746031.pdf

International Labour Organisation (ILO). (2019). Working on a warmer planet: The effect of heat stress on productivity and decent work. https://www.ilo.org/global/publications/books/WCMS 711919/lang--en/index.htm

IPCC, 2021: Climate Change 2021: The Physical Science Basis. Contribution of Working Group I to the Sixth Assessment Report of the Intergovernmental Panel on Climate Change [Masson-Delmotte, V., P. Zhai, A. Pirani, S. L. Connors, C. Péan, S. Berger, N. Caud, Y. Chen, L. Goldfarb, M. I. Gomis, M. Huang, K. Leitzell, E. Lonnoy, J. B. R. Matthews, T. K. Maycock, T. Waterfield, O. Yelekçi, R. Yu and B. Zhou (eds.)]. Cambridge University Press. In Press.

Jackson, L., \& Pang, M.-F. (2017). Secondary school students' views of climate change in Hong Kong. International Research in Geographical and Environmental Education, 26(3), 180-192.

Jasmina, S. (2019). Plant a Tree! Climate change communication and perception in rural

Uganda. University of Agder, Faculty of Social Sciences Department of Global Development and Planning.

Karen, B. (2019). Climate Change is a youth issue. Global Human Development Program at Georgetown University

Karpudewan, M., Roth, W.-M., \& Chandrakesan, K. (2015). Remediating misconception on climate change among secondary school students in Malaysia. Environmental Education Research, 21(4), 631-648. 
Katharine, L., Nathalia, G., Saffron, O., \& Julie, B. (2020). Youth perceptions of climate change: A narrative synthesis. WIREs Climate Change, 11, 1-24. https://doi.org/10.1002/wcc.641

Kenya: The Constitution of Kenya [Kenya], 27 August 2010, available at: https://www.refworld.org/docid/4c8508822.html [accessed 12 December 2020]

Kiaras, G. \& Ben A-N. (2018). In a world of "Us" and "Them": the case against intervention-focused research, Child \& Youth Services, 39:2-3, 97-100, DOI: 10.1080/0145935X.2018.1531510

Kiaras, G., \& Ben, A-N. (2017). Children and youth in the era of climate change, Child \& Youth Services, 39:4, 207-210, DOI: 10.1080/0145935X.2018.1557882.

Kilinc. R. (2018). Ugandan Government Steps Up Efforts to Mitigate and Adapt to Climate Change, Feature article. World Bank.

Klara, F., \& Hajdu, F. (2017). The importance of the will to improve: how 'sustainability' sidelined local livelihoods in a carbon-forestry investment in Uganda, Journal of Environmental Policy \& Planning, DOI: 10.1080/1523908X.2017.1410429.

Kleres, J. \& Wettergren, A. (2017). Fear, hope, anger, and guilt in climate activism, Social Movement Studies, 16:5, 507-519, DOI: 10.1080/14742837.2017.1344546

Kurt, B. 2015. The Role of Youth in Natural Resource Management: An Analysis for USAID/Cambodia's Environment Project Design Process, Kampuchean Action for Primary Education, Cambodia.

Kwadwo A. S. Ahmad, A., Komla, D.; Bright, A., \& Daniel, A. (2018) Assessment of rice farmers' knowledge and perception of harvest and postharvest losses in Ghana, Cogent Food \& Agriculture, 4:1, DOI: 10.1080/23311932.2018.1471782

Lee, H. (2020). Time to get serious about climate change. On a warming planet, no one is safe. UNEP.

Mfitumukiza, D. 2021. Climate Change and the Development of Uganda. Keynote lecture, at the Kampala-Cambridge Workshop 2021: Young people, climate disruption \& adaptation in Africa. 12th July 2021, online.

Marijn, F. (2018). Policy changes in the food-climate nexus. PhD thesis, Department of Social Sciences, Wageningen University.

Masuda, Y. (2019). How are healthy, working populations affected by increasing temperatures in the tropics? Implications for climate change adaptation policies. Global environmental change 56, 29-40. DOI: 10.1016/j.gloenvcha.2019.03.005. 
Ministry of Gender, Labour and Social Development (Uganda). (2020). Retrieved on January 16, 2021 from http://www.gou.go.ug/ministry/ministry-gender-labour-andsocial-development

Muhumuza, M., Muzinduki, P., and Hyeroba, G. (2011). Small holder farmers' knowledge and adaptation to climate change in the Rwenzori region. A research journal of the Rwenzori Think Tank Initiative, 117-133

Mugyenyi, O., Mugeere, A., \& Amumpiire, A., A. (2020). Conserving the Environment and Enhancing Community Resilience: The Key Climate Change Priorities during and after COVID-19, Kampala: ACODE, Policy Briefing Paper Series No.53.

Nagasha, J., Mugisha, L., \& Kaase-Bwanga, E. (2019). Effect of climate change on gender roles among communities surrounding Lake Mburo National Park, Uganda, Emerald Open Research, https://doi.org/10.12688/emeraldopenres.12953.2

Nakabuye Hilda Flavia. (2019). Why I joined the strike for climate change: Fridays For Future Uganda. We Are Restless. Published 14.9.2019. Accessed on 11.8.2021 from: https://wearerestless.org/2019/05/14/why-i-joined-the-strike-for-climate-change-fridays-forfuture-uganda/

Nansambu, D. \& Sugden, F. (2017). A generation on the move: voices of youths in the context of climate change, migration, and livelihood transition. Session Report from the 11th International Community Based Adaptation Youth Conference, Kampala, Uganda, 26-29 June 2017.

Nairn, K. (2019) 'Learning from Young People Engaged in Climate Activism: The Potential of Collectivizing Despair and Hope', YOUNG, 27(5), pp. 435-450. doi: 10.1177/1103308818817603.

National Environmental Justice Advisory (NEJAC). (2018). Climate Changes Health: Ensuring Environmental Justice Underlies Public Health's Climate Change Work. Washington D.C. American Public Health Association - Environmental Justice Subcommittee.

National Planning Authority (NPA). Third National Development Plan (NDPIII), 2020/2021/2024/2025. Ministry of Finance, Planning and Economic Development, Kampala, Uganda.

Njeri, W. (2017). Mobile Gambling Among Youth In Sub-Saharan Africa. In African Youth, GeoPoll Survey Reports.

Nyasimi, M., Ayanlade, A., Mungai, C., Derkyi, M. \& Jegede, M. O. (2018). Inclusion of Gender in Africa's Climate Change Policies and Strategies. in Handbook of Climate Change Communication: Vol. 1 171-185 (Springer, 2018). DOI: 10.1007/978-3-319-69838-0_11 
Nyasimi M, Radeny M, Mungai C, Kamini C. (2016). Uganda's National Adaptation Programme of Action: Implementation, Challenges and Emerging Lessons. CGIAR Research Program on Climate Change, Agriculture and Food Security (CCAFS). Copenhagen, Denmark Available online at: www.ccafs.cgiar.org

O'Higgins, N. (ed) (2017) Rising to the Youth Employment Challenge: New evidence on key policy issues. Geneva: International Labour Organisation. Available at https://www.ilo.org/global/publications/books/WCMS_556949/lang—en/index.htm

Okalebo, S. (2015). Livelihood Strategies of the Rural Uneducated Married Youth in Kobwin Sub-county, Ngora district. MA Dissertation, Department of Community and Adult Education, Makerere University, Kampala, Uganda.

Opio, E. 2019. Influence of climate change on household food security in Uganda: A case study of Luweero District. MA thesis prepared for Nkumba University. http://nuir.nkumbauniversity.ac.ug/bitstream/handle/20.500.12383/737/OPIO\%20ES AU-SOSS.pdf? sequence $=1$ \&isAllowed $=y$

Oriangi, G., Albrecht, F., Dibaldassarre, G., Bamutaze, Y., Isolo Mukwaya, P., Ardö, J., \& Pilesjö, P. (2020). Household resilience to climate change hazards in Uganda. International Journal of Climate Change Strategies and Management, 12(1), 59-73. https://doi.org/10.1108/IJCCSM-10-2018-0069

Osuret, J., Atuyambe, L., Mayega, R., Ssentongo, J., Tumuhamye, N., Mongo, B., Tuhebwe, D., \& Bazeyo, W. (2016). Coping Strategies for Landslide and Flood Disasters: A Qualitative Study of Mt. Elgon Region, Uganda. PLOS Currents Disasters. Edition doi:10.1371/currents.dis.4250a225860babf3601a18e33e172d8b."

The Oxford Compact English Dictionary. Oxford, England: Oxford University Press.

Puttick, G., Kies, K., Garibay, C., \& Bernstein, D. (2015). Learning and behavior change in a Girl Scout program focused on energy conservation: Saving energy to 'save the planet'. Journal of Sustainability Education, 8, 1.

Ramadhani, H. (2019). Assessment of motives for sports betting among youth in Tanzania: A case study of Kinondoni District. Mzumbe University, Dar es Salaam, Tanzania.

Rietveld, A., Margreet, V., \& Groot, J. (2020). Bridging youth and gender studies to analyse rural young women and men's livelihood pathways in Central Uganda. Journal of Rural Studies 75 (2020) 152-163. 
Ritchie, J. \& Spencer, L. (1994). Qualitative data analysis for applied policy research" by Jane Ritchie and Liz Spencer in A.Bryman and R. G. Burgess [eds.] "Analyzing qualitative data", 1994, pp.173-194.

Sambunjak D, Cumpston M, Watts C. Module 1: Introduction to conducting systematic reviews. In: Cochrane Interactive Learning: Conducting an intervention review. Cochrane, 2017. Available from https://training.cochrane.org/interactivelearning/module-1-introduction-conductingsystematic-reviews.

Sanson, A. V., Van Hoorn, J., \& Burke, S. E. (2019). Responding to the Impacts of the Climate Crisis on Children and Youth. Child Development Perspectives, 13(4), 201-207.

Salami, A; Kamara, A.; Brixiova, Z. (2018), Smallholder Agriculture in East Africa: Trends, Constraints and Opportunities, Working Papers Series No. 105 African Development Bank, Tunis, Tunisia.

Scott-Parker, B., \& Kumar, R. (2018). Fijian adolescents' understanding and evaluation of climate change: Implications for enabling effective future adaptation. Asia Pacific Viewpoint, 59(1), 47-59.

Shakespeare, T., Mugeere, A., Nyariki, E. \& Simbaya, J., (2019). 'Success in Africa: People with disabilities share their stories', African Journal of Disability 8(0), a522. https://doi.org/10.4102/ajod.v8i0.522

Tenywa, J., Nabasirye, M., Twinomuhangi, R., \& Mfitumukiza, D. (2017). Uptake of Knowledge and Technologies for Adaptation to Climate Change in Crop Production Systems in Uganda: A Review. Advances in Research 1-14. DOI: 10.9734/AIR/2017/34892.

Toulmin, C. (2009). Climate change in Africa. Zed Books, London.

The United Republic of Tanzania. (2007). National Youth Development Policy. Ministry of Labour, Employment and Youth Development, Dar es Salaam, Tanzania.

Uganda Bureau of Statistics (UBOS). (2017). The National Population and Housing Census 2016 - Main Report, Kampala, Uganda.

Uganda: Constitution of the Republic of Uganda, (1995). Kampala, Uganda.

United Nations Framework Convention on Climate Change (UNFCCC). 2016. Adoption of the Paris Agreement, Decision 1/CP.21, in COP Report No. 21, Addendum, at 2, U.N. Doc. FCCC/CP/2015/10/Add.1.

UNCDP (United Nations Committee for Development Policy). 2020. List of Least Developed Countries (as of December 2020). Accessed 2.2.2021 from 
https://www.un.org/development/desa/dpad/wp-

content/uploads/sites/45/publication/ldc list.pdf

UNEP (United Nations Environment Programme). No date. Responding to climate change. Accessed on 20.1.2021 from:

https://www.unenvironment.org/regions/africa/regional-initiatives/responding-climatechange

The Republic of Uganda: National Youth Policy. (2001). Policy document, Kampala, Uganda.Retrieved on January 25, 2021 from: https://www.youthpolicy.org/national/Uganda 2001 National Youth Policy.pdf

Thew, P. (2018). State of the Climate in 2018 Shows Accelerating Climate Change Impacts. A Call to Action, United Nations, New York.

United Nations. (2016b). The Emissions Gap Report 2017 A UN Environment Synthesis Report. United Nations Environment Programme, Nairobi.

United Nations Framework Convention on Climate Change (UNFCCC). (2016). Work programme on results-based finance to progress the full implementation of the activities referred to in decision 1/CP.16, paragraph 70. Decision 9/CP.19. Report of the conference of the parties on its nineteenth session, Warsaw, 11-23 November 2015. FCC/CP/2015/10 Add.1. United Nations Framework Convention on Climate Change, Bonn, Germany. http://unfccc.int/resource/docs/2013/cop19/eng/10a01. pdf.

Uprichard (2008). 'Children as 'Being and Becomings': Children, Childhood and Temporality'. Children and Society, 22, 303-313

USAID. (2019). Uganda Country Climate Risk Assessment Report. Irish Aid, Resilience and Economic Inclusion Team, Policy Unit.

Wetaya, R. (2020). Ugandan police arrest activists demanding climate action. Alliance for Science. Accessed on 11.8.2021 from: https://allianceforscience.cornell.edu/blog/2020/09/ugandan-police-arrest-activistsdemanding-climate-action/

Wilks, L., \& Harris, N. (2016). Examining the conflict and interconnectedness of young people's ideas about environmental issues, responsibility and action. Environmental Education Research, 22(5), 683-696.

World Bank. (2018). Climate Change Could Force Over 140 Million to Migrate Within Countries by 2050: World Bank Group, Washington, USA. 
Youth. (2019). In Oxford Online Dictionary. Retrieved from https://en.oxforddictionaries.com/definition/youth 